\title{
Uterine Hemorrhage
}

National Cancer Institute

\section{Source}

National Cancer Institute. Uterine Hemorrhage. NCI Thesaurus. Code C78686.

Bleeding originating from the uterus. 